\title{
Russia:
}

\section{Modern Problems of Arbitration in Land Disputes}

\author{
Aleksey ANISIMOV \\ Vladimir GAVRILENKO
}

\begin{abstract}
The article is devoted to the issues of the legal regulation of the procedure of dispute resolution in the sphere of land use and protection by arbitral tribunals. The authors prove the need to adjust the Russian legislation on arbitral tribunals, that artificially limits their number and thereby prevent the access of economic activity subjects to justice. Particular attention is paid to the need to strengthen the legal force of arbitral awards on land disputes, including the consolidation of their right to issue writs of execution that are compulsory for the state registration bodies for registration of the rights to real estate without coming to the state courts of General Jurisdiction. The development of the system of arbitral tribunals and their competence will help

Aleksey ANISIMOV, PhD to strengthen the guarantees of land and other economic rights of Russian entrepreneurs.
\end{abstract}

Professor of Constitutional and

Administrative Law Department, Volgograd Institute of Management

- Branch of the Russian Presidential

Academy of National Economy and

Public Administration

e-mail: anisimovap@mail.ru

Vladimir GAVRILENKO, PhDc

Associate Professor of Theory and History of State and Law department, Saint-Petersburg University of State

Fire Service of EMERCOM of Russia e-mail: gv22@mail.ru

Conflict Studies Quarterly

Issue 28, July 2019, pp. 3-15

DOI:10.24193/csq.28.1

Published First Online: 28/06/2019
Keywords: arbitral tribunal; arbitration proceedings; land; natural object; natural resource; non-state justice; judges.

\section{Introduction}

Arbitration is an alternative to state justice and it is carried out by a non-state independent organization. The possibility of the influence of public authorities on the disputes resolution is insignificant. Arbitral tribunals are not the judicial authorities and therefore are not included in the judicial system of the Russian Federation.

The objective of the arbitration is to settle legal conflicts and ensure the voluntary ex- 
ecution of obligations. This objective is represented in the fact that arbitration is chosen by the disputing parties themselves who voluntarily entrust the decision making on their case to a certain arbitration institution and undertake to follow this decision in advance. The power of the arbitral tribunal is based not on the General law but on the contractual principle and the will of individuals. Arbitration trial of disputes and international commercial arbitration are sometimes called "private justice" not accidentally (Lebedev, 1999, p. 62).

Arbitration is one of the most appropriate forms of jurisdiction for the market economy, as it involves the possibility of choosing arbitrators from the amount of qualified independent specialists on the initiative of the parties of the conflict and, therefore, implies an individual approach to every particular dispute. The existing opportunity for the parties to choose a judge on their own is one of the basic principles of the organization of the arbitration proceedings and an important factor in protecting the rights and interests of the parties.

The most significant aspect of the legal nature of the Institute of arbitration is its nonstate pattern that makes it possible to distinguish it from the state court. The arbitral tribunal has the competence to consider a dispute only in case if there is an arbitration agreement between the parties that confirms the existence of a clear consent of both parties. The state court is a body of the judicial power that has competence due to the direct reference of the national law, not by agreement of the parties. Therefore, the state court and arbitration tribunal are independent legal institutions of different legal nature. It seems that the arbitration trial of disputes is an important part of the legal sphere of non-state economic justice.

There is no doubt that each type of the economic activity has its own specific features that must be taken into account and this leaves its mark both on the choice of arbitrators and on the cases considered. Therefore, further we will try to examine the existing types of arbitral tribunals, their advantages and competence, and also we will try to prove the advantages of non-state justice by the example of land disputes resolution.

\section{Competence and types of arbitral tribunals in the legislation of Russia}

\subsection{Competence of arbitral tribunals}

The mandatory condition for the dispute to be redirected to the arbitral tribunal is the existence of a valid arbitration agreement between the parties. "The conditions of validity of the arbitration agreement are determined in accordance with the civil law applicable to civil transactions" (Vladimirova, 2007, p. 14). The parties conclude this agreement voluntarily and independently determine what elements it will consist of. They voluntarily agree on the arbitrators who will consider the dispute and on the compulsory and voluntary execution of the decision of the stated arbitrator. 
The interest of the parties in the proceedings is in the arbitration trial of disputes and in the judgment delivered by a third party not interested in the matter of the dispute. As a result, the dispute is finally resolved. The arbitration agreement shall be in writing and it shall constitute a separate document or be contained in another document signed by the parties or shall be concluded by an exchange of letters or other communications fixing such agreement. The rules on compliance with the written form of the arbitration agreement almost completely coincide with the procedure for concluding the contract in writing. There is an interesting situation with a contract that has not entered into force, but contains an arbitration clause, which took place in the award of the American arbitration in the case of Republic of Nicaragua v. Standard Fruit Co. The contract contained a clause on the consideration of the dispute in arbitration, but negotiations regarding the main contract were not completed. However, the above dispute was referred to arbitration (Kanashevsky, 2006, pp. 646-647).

Arbitration tribunals are subject to disputes between the parties to civil law relations, including individuals and legal entities, unless otherwise provided by law. Some types of disputes cannot be considered by arbitration courts because they are public-legal. It is necessary to specify the main types of these disputes, including disputes on consumer protection, disputes on contracts in the field of public procurement, disputes in the field of antitrust regulation, disputes on the privatization of state and municipal property, disputes on bankruptcy, etc.

\subsection{Types of arbitral tribunals in Russia}

Arbitral tribunals in Russia are now divided into two types: permanent arbitration institutions and single-time ( $\mathrm{ad} \mathrm{hoc}$ ), created for consideration of a particular dispute. The rules adopted by these arbitration institutions are applied to the activities of the permanent arbitration institutions. The set of the above rules is called the regulations of the appropriate arbitration institution. Finding resolution to a dispute in an isolated arbitration (ad hoc) established to consider a particular dispute, the arbitrators and the parties of the dispute should determine the procedural rules which they will follow. They may develop such rules themselves or agree that their dispute will be resolved in accordance to the model arbitration rules. It should be noted that "the courts for the resolution of a particular dispute differ most significantly from the permanently functioning arbitration courts by the fact that they do not have the rules that the arbitration trial has" (Skvortsov, 2010, p. 11). "The advantages of ad hoc arbitration are possibly to become apparent when it is used towards a dispute that has already appeared. Knowing the nature of the dispute and having an understanding of the circumstances related with the dispute, the parties may work out their ad hoc rules so that they correspond properly with the requirements of the particular dispute" (Huleatt-James \& Gould, 1999, p. 35). 
Further, we will analyze the legal status of permanently functioning arbitration institutions. The current Federal law N 382-FZ dated December 29, 2015 "On arbitration (arbitration tribunal) in the Russian Federation" established new rules for their arrangement. Previously, these institutions could be created under any legal entity; now, only under non-profit organizations (NPOs) that have the right to carry out the functions of a permanently functioning arbitration institution.

The right to carry out the above-stated functions is granted to the NPOs by the government of the Russian Federation on the recommendation of the Council for the improvement of the arbitration that was established under the Ministry of Justice of the Russian Federation. It includes the representatives of the state bodies (no more than $1 / 3$ ), chambers of Commerce and Industry, public associations of lawyers and entrepreneurs. The Council mentioned above takes into account the reputation and field of activity of the non-profit organization where the arbitration institution is established. Also, the attention is paid to the list of arbitrators and their professional reputation.

The procedure of getting the recommendation of the Council and the subsequent permission of the Government of the Russian Federation is rather strict. This is evidenced by the fact that, at present, only two permanently functioning arbitration institutions have received the right to carry out their activities (the Arbitration Centre at The Russian Union of Industrialists and Entrepreneurs and the Arbitration Centre at the Institute of Modern Arbitration).

Moreover, it is pointed out in the Russian legislation that the International Commercial Arbitration Court at the Chamber of Commerce and Industry of the Russian Federation and the Maritime Arbitration Commission at the Chamber of Commerce and Industry of the Russian Federation have the right to carry out their functions without the additional right to such activities. The above-mentioned institutions belong to the sphere of international commercial arbitration and they are the oldest arbitration institutions in the Russian Federation. The International Commercial Arbitration Court (ICAC), a former Foreign Trade Arbitration Commission, was founded in 1932. The Maritime Arbitration Commission (MAC) was founded in 1930. The activity of these organizations is regulated by the Federal law N 5338-1 dated July 7, 1993 - On international commercial arbitration.

Thereby, in Russia, arbitration institutions can be divided into international commercial arbitration and "internal" arbitral tribunals that resolve disputes of subjects within the country (Alekseev, 2012, pp. 4-5). International commercial arbitration is an arbitral tribunal, the main purpose of which is to hear an international commercial dispute in accordance with the determined procedural order; that results in the decision making is compulsory for both parties. Let us note that the presence of an extensive international legal framework has great importance for the international commercial arbitration. Its activity is based on a large number of international conventions. International commer- 
cial arbitration is created in order to resolve disputes of special category, particularly disputes arising from civil law and mainly trade transactions that include a mandatory "foreign element" in one form or another. The parties of the considered dispute should belong to different legal systems and national jurisdictions.

\section{Advantages of arbitration}

The arbitral tribunal has a number of advantages over ordinary commercial dispute resolution. The trial is conducted only by the tribunal if there is an agreement of the parties on its mandatory nature. There is a limited number of cases when it can be contested. The arbitral tribunal is a contractual legal institution. It is based on a voluntary agreement between the parties. It is unacceptable to enforce economic entities to arbitration trial without their voluntary consent. As an example, the case of the ICAC № $77 / 2002$, where the claim was filed by a Russian company against a Polish company in connection with non-payment of the goods delivered. The competence of the ICAC was determined directly in clause 11.1 of the contract between the parties to the dispute. This contract provided that dispute resolution falls under the jurisdiction of the ICAC in accordance with its Regulations (Rosenberg, 2004, p. 259).

The parties of the arbitration trial have incomparably broader rights to determine the place of the arbitration trial, the applicable law and/or the dispute resolution procedure. The parties of the dispute can choose the arbitrators on their own, whom they trust more and whose competence is the most suitable to the subject of the dispute.

It is obvious that the ability to choose the arbitrator on your own is the most important principle of the arbitral proceeding and also it is an important factor in protecting the rights and interests of the parties in the arbitration trial. The ability to choose the arbitration allows the parties not to be limited by the place of residence of the citizen or the location of the legal entity.

The choice of applicable law in arbitration allows the parties of the dispute to determine the most appropriate legal system for resolving possible conflicts. Accordingly, this allows the representatives of the parties to avoid the work in an unfamiliar legal system where the interests of the parties cannot be protected effectively. We consider as an example the case of the ICAC № 58/2005 about the cancellation of the contract of sale of petroleum products. Russian law was recognized as applicable to the substance of the dispute, since clause 12 of the Contract contained the following provision. This provision says that "The parties to this contract have agreed that the applicable law in the resolution of disputes arising during the execution of the contract is the civil law of the Russian Federation" (Archive of ICAC, case № 58/2005). There is also the interesting case of ICAC № 95/2002. The claim was filed by a Russian company against a Swiss company in connection with the incomplete payment of the goods delivered under the contract. The claimant demanded repayment of the amount of the debt and also reimbursement of 
expenses connected with the proceedings. At the time of contacting the ICAC, there was no agreement on applicable law between the parties. But, during arbitration, the parties agreed to apply Russian law to relations under this contract (Rosenberg, 2004, p. 62).

It should be noted that "one of the generally recognized undeniable advantage of case consideration by the arbitral tribunal instead of by the state courts at all times and in all states was its efficiency" (Zaitsev, 2017, p. 176). The efficiency of dispute resolution by the arbitral tribunal is connected with the fact that its regulations or the rules negotiated by the parties themselves in the arbitration agreement may not provide the use of a number of procedures that entail an increase in the period of the case consideration. Arbitration is less formalized in comparison with the state proceedings that leads to the rapid dispute resolution which, in turn, causes the costs reduction.

It seems that justice, that has to deal with a huge number of claims in short procedural terms with a limited number of judges, is frequently able to cope with the set task at the expense of the quality of the trial. The dissatisfaction of the parties because of the quality of the court decision gives rise to a long process of appeals at higher authorities that can last for years. We also should note the aspect of confidentiality. Hearings in the arbitral tribunal are not public, are held in private, unauthorized people are not allowed to attend, its decisions are not published in the media and on the Internet and only the parties receive copies of the decisions (Bryzhinsky, 2005, p. 26).

Any information that becomes known during the dispute resolution process is kept confidential. Current legislation codifies the above principle. It provides the witness immunity of arbitrators who are relieved of the obligation to give evidence on circumstances that have become known to them during the execution of their obligations.

The requirement on confidentiality of the arbitration trial should be applied not only to the arbitrators but also to people executing the functions of principals (chairman, vicechairman) and to the staff of the permanently functioning arbitral tribunal (executive secretary, secretary, typists, other employees).

\section{Arbitral award and its execution}

Some legal scholars point out the principle of the arbitral award finality (Tarasov, 2002; Chupakhin, 2015). This opinion is debatable because, in the current legislation, there is a possibility of challenge and even cancellation of the arbitral award on a number of established bases. Also, there is a possibility to appeal the decision of the state court for the issuance of a writ of execution on the arbitral award. It seems that unfair party may, at least, delay the execution of the decision of the arbitration tribunal using the regulations of the current legislation. Positive experience in execution of arbitral awards has already been accumulated in a number of world countries. In order to carry out its dispute resolution function, the judicial system needs a mechanism that ensures the end 
of the dispute. The courts have worked out a doctrine of prevention in order to ensure the finality of decisions. Preventing a claim prevents a party from filing a claim with the same subject with which it was previously filed to another court.

The doctrine of prevention a lawsuit interferes disputes consideration that was determined to the required extent in the previous case, even though the following claim may concern another subject. Prevention rules help to preserve judicial resources, interferes inconsequent decisions, eliminate unnecessary litigation delivering anxiety and promote public confidence in justice. Prevention is not provided when the opposing party can prove that it didn't have an opportunity to fully state its position in a previous case towards the dispute under consideration (Cound, Friedenthal, Miller, Sexton, 1989, p. 1084). The above-mentioned doctrine of prevention applies to both state courts and non-state arbitrations.

At the same time, the grounds for challenging arbitral awards are much less than towards the decisions of state courts. However, in the later case, it may take a long time before a final decision is made in the case. The inadmissibility of appealing an arbitral award on the matter of the dispute is an important factor in speeding its consideration and making a final decision. Considering the principle of finality of the arbitral award, let's note that "it is possible to talk about the existence of this principle only in cases when the rules of permanently functioning arbitral tribunals fixed the rule on finality of the decision and the parties have not agreed on other rules of the case" (Kurochkin, 2007, p. 156).

From those above, it can be concluded that the principle of finality of arbitral awards works in practice, but at the same time, the finality of the arbitral award is relative. In case of non-execution of the arbitral award voluntarily, the parties have the opportunity to use the mechanism of state coercion and have the right to apply to the state court for the issuance of a writ of execution for the enforcement of the arbitral award. The grounds on which a state court may refuse to enforce an arbitral award are limited. The grounds that allow state courts to refuse in the enforcement of arbitral awards are issues of applicable law, issues of compliance of the dispute procedure with the arbitration agreement, etc.

Even though state courts don't formally have the opportunity to review the acts of arbitral tribunals, in fact, however, they often act, essentially, as an appellate instance in relation to the system of arbitral tribunals and international commercial arbitration. The decision of the arbitral trial towards which there was received a writ of execution for its enforcement, in its legal force it is equivalent to the judicial acts of the courts of general jurisdiction and state economy courts that have come into legal force. Possibly, in the future, the use of various measures to encourage enforcement, similar to those applied towards the decisions of state courts. The possibility of mandatory enforcement and international recognition of the arbitration award take place almost everywhere in the world. Arbitral awards achieve international recognition not rare than decisions 
of state courts. The United Nations Convention «On the recognition and enforcement of foreign arbitral awards» of June,10 1958, known as the "New York Convention", has been ratified by a majority of the world countries. Besides this, the «European concept of foreign trade arbitration» of April, 211961 is in force. The above-mentioned conventions provide a single mechanism for all the member countries to recognise and enforce decisions with the help of certain state courts, in due course.

In the legal literature, proposals are made to give, as an experiment, to one or more arbitral tribunals the authority to issue a writ of execution on their own decision, similar to the writ of execution of the state court (Gavrilenko, 2007, p. 154).

If the results of this practice are positive it is necessary to use it everywhere and make appropriate changes to the legislation. In our opinion, this idea is attractive because the state court that issues the writ of execution for the decision of the arbitration tribunal did not consider the case on the merits, and has a worse idea about it than the corresponding arbitration tribunal. Therefore, the issuance of the writs of execution by arbitral tribunals will make the process of the decisions execution faster and less bureaucratic. The proposal mentioned above does not apply to the decisions of the international commercial arbitrations, as the named organizations are usually located in a different state than the one where their orders are to be enforced. Therefore, it is advisable to the participation of the state courts.

\section{Land disputes resolution by the arbitral tribunal}

The land is the essential component of the natural environment. Its value also is in the fact that it is the means of production in agriculture and forestry, the spatial basis of economic and other activities, the object of civil turnover. This value of land assumes the concentration of the interests of different stakeholders around it and the occurrence of contentious relationships due to violations of the rights of land owners and land users by the other person. And if one party supposes that the rights have been violated, there a land dispute takes place (Perozhok, 2017).

Under the "resolution of land disputes", legal science usually means the activity of courts of general jurisdiction, state arbitration courts and arbitral tribunals regulated by the rules of land, civil, civil procedure and arbitration law, aimed at the elimination of the disagreements between the disputing parties, the prevention of the subjective land rights and interests realization, as well as determination and restoration of the violated rights or understanding of the rights and obligations of the dispute parties. Land disputes are considered by the courts in accordance with the rules on cognizance and jurisdiction of disputes established by the procedural legislation of the Russian Federation" (Harlamova, 2009, p. 208). To distinguish land disputes from other categories of cases in the scientific literature, it is proposed to allocate the procedural criterion. This criterion is the nature of the claims of the parties, their relationship 
with the protection of land rights and interests. Thus, if the claim of the parties of the dispute is aimed at elimination, suppression of violations of land rights and interests, the dispute can be declared as land, if the elimination of violations of other rights is primary, for example, in the field of water use, it is impossible to talk about the existence of a land dispute (Emaltynov, 2012).

There are several classifications of land disputes. Thus, some authors distinguish land, land and property and property disputes (Krapan, 2009, p. 20). Other authors suppose that land disputes can be differentiated on the following criteria: reasons of occurrence, subject composition, the affiliation of the object of the dispute (the land) to certain categories of the land fund, the status of the object (the earth as a natural object or an object of immovable property), the subject, the parties of dispute, the groups (pure land; land and property, property disputes arising from land relations, complaints about the actions of the public authorities, administrations of enterprises, institutions, organizations) (Fedorova, 2004, P. 16). Meanwhile, let us note that despite their undoubted advantages, these classifications are debatable for the following reasons.

In our opinion, the generic classification of land disputes includes two groups: on the use and on the protection of land, as these two groups of public relations makes the subject of land law as a branch of law. Within each of them, several species of varieties can be identified. Therefore, within the group of disputes on the use of land, it is possible to distinguish disputes on the right of ownership (other real rights to land), contractual disputes (related to the occurrence, execution or termination of lease rights to land), disputes arising from the relations on the management of the land fund (on the boundaries of the area, the parameters of its development, cadastral registration of the area, registration of ownership, etc.), disputes on the validity of legal liability, etc. Disputes related to the protection of land arise when the land as a natural object is harmed, for example, due to the destruction of the fertile soil layer, violation of the regime of lands of specially protected natural areas (reserves, national parks, etc.).

It follows that arbitral tribunals don't have the right to consider all the categories of land disputes. Thus, they do not resolve disputes on the recognition of ownership on ownerless of real estate or towards a land area on which a person has a right as a result of acquisitive prescription ${ }^{1}$, as in these cases the claims are not related to a dispute arising from specific legal relations in which the parties are entitled to carry out administrative actions (Sevastyanov, 2013). Similarly, most of the land disputes related to appeals against management decisions or damage to land as a natural object in public ownership are outside their competence.

1 In the Russian civil law, the term acquisitive prescription means that a citizen or legal entity faithfully, openly and continuously have owned "as his" the land area not belonging to him for 15 years, he has the right to demand the transfer of this area to private ownership. 
However, a significant part of property land disputes can still be considered by the arbitral tribunals. The basis for consideration of land disputes by the arbitral tribunal is the article 64 of the Land Code of the Russian Federation, according to which land disputes are considered in court. Also, before taking the case to the court, the land dispute can be sent by the parties to the arbitral tribunal. The Constitutional Court of the Russian Federation pointed out on this issue that the provisions of laws allowing arbitral tribunals to consider civil disputes relating to real estate, and the state registration of relevant rights based on the arbitral award, do not contradict the Constitution of Russia. This conclusion applies to the land property.

Meanwhile, despite the importance of these explanations, they do not remove all the problems arising during the resolution of land disputes by the arbitral tribunals. One of such controversial issues concludes that in the scientific literature the idea that arbitral tribunals cannot make decisions on the rights of land property, compulsory for the authorities carrying out state registration of rights to real estate (including land) is widespread as the dispute can not affect the interests of third parties (Shekunova, 2018).

The court practice confirms that the absence of a writ of execution issued by the state court for the enforcement of the decision of the arbitration court on the recognition of ownership of real estate is the basis for the refusal in the state registration (Petrenko, 2016).

Meanwhile, it is difficult to agree with such theory and practice, because of the following:

1. one of the principles of the arbitral tribunal work is really confidentiality. However, consideration of the dispute in the arbitral tribunal regarding the land area that is owned (or otherwise) by a third party (or affecting its interests protected by law) without its proper notification will mean that the latter has the opportunity to challenge the arbitral award or apply to the state court with an independent claim to protect the rights.

2. the need to get a writ of execution in the state court undermines the credibility to the arbitral awards and impugns one of the principles of its work related to the prompt and effective consideration of cases and making decisions. In this regard, it seems that the legislation on the state registration of rights to real estate should be supplemented by the regulations establishing the obligation to register the rights to real estate directly by the arbitral award. Accordingly, it is impossible to agree with the proposal to restrict artificially the right of citizens and legal entities to choose the form of protection of subjective land rights by prohibiting arbitration trial.

It seems that arbitral tribunals have the right to consider any disputes, except the cases of direct legislative restrictions. The development of the system of arbitral tribunals is also important and necessary because, at the present moment, in the scientific literature, there is a discussion about the practicability of the specialized land courts creation 
within the system of general jurisdiction courts, as it will improve the protection of the rights and legitimate interests of land disputes (Melnikov, 2017).

There is a necessity to create constantly functioning specialized arbitral tribunals that resolve only land disputes. They need to develop practical experience of specialized land courts, which is then, will be extended to the state courts.

\section{Conclusion}

At present moment after the next stage of the arbitral tribunals reform, connected with the fact that the Federal law № 382-FZ dated December, 292015 "On arbitration (arbitration tribunal) in the Russian Federation" came into force, significant changes in the legal regulation of the jurisdiction of the arbitral tribunals have been made. The main novelties of the current law are in the toughening of the rules for the establishment and registration of permanently functioning arbitral tribunals that is carried out by the Russian Government on the recommendation of the Council for the improvement of arbitration, created under the Ministry of Justice of the Russian Federation. This procedure is quite strict and formalized, it resulted in a significant reduction in the number of permanently functioning arbitral tribunals. There is a practice when the Council refuses to give in its recommendations the right to the realization of activities by a permanently functioning arbitral tribunal on formal and contrived grounds. This situation causes a serious problem of the actual lack of the possibility of dispute resolution in the arbitral tribunals for the majority of business entities, as in fact arbitration trial has become an elite way of dispute resolution.

It seems sensible to change the policy of the Ministry of Justice of the Russian Federation and the Council for the improvement of arbitration in order to reduce the formalities that prevent the resolution of the activities of permanently functioning arbitral tribunals. This is especially important for the consideration of land disputes by the arbitral tribunals as their advantages are obvious: the complexity of this category of cases; the high cost of land property; the need for prompt and confidential resolution of the dispute; the ability to maintain business relations between the parties of the dispute, etc.

The strengthening of the legal force of the arbitral awards (in particular, in the field of state registration of rights to land property) will increase the confidence in the system of arbitral tribunals by the business community and will discharge the state courts.

\section{References}

1. Alekseev, M. A. (2012). Transformation of the role and legal basis of the competence of the International Commercial Arbitration Court in modern economic activity. PhD thesis presented at the Law faculty, Volgograd State University.

2. Bryzhinsky, A. A. (2005). Alternative resolution of legal disputes and conflicts in Russia. $\mathrm{PhD}$. Thesis presented at the Law faculty, Lobachevsky State University. 
3. Chamber of Commerce and Industry of the Russian Federation (2005). Case no. 58/2005. Moscow: Archive of the International Commercial Arbitration Court.

4. Chupakhin, I. M. (2015). Arbitral award: theoretical and applied problems. Moscow: Infotropic.

5. Cound, J., Friedenthal, J., Miller, A., \& Sexton, J. (1989). Civil Procedure: Cases and Materials / 5th ed. St Paul: West Publishing Co.

6. Emaltynov, A. R. (2012). Procedural features of consideration of land disputes. PhD thesis presented at the Ural State Law Academy, Ekaterinburg.

7. Fedorova, Y. N. (2004). Resolution of land disputes under the legislation of the Russian Federation. PhD thesis presented at the Saratov State Academy of Law.

8. Gavrilenko, V. A. (2007). Arbitration (Manual). Veliky Novgorod: Publishing Center of NovGU.

9. Harlamova, O. A. (2009). Land disputes. Theory and practice solution. Proceedings of the Orenburg state agrarian University, 4, 208-209.

10. Huleatt-James, M., \& Gould, N. (1999). International commercial arbitration. London: LLP.

11. Kanashevsky V. A. (2006) International private law (Manual). Moscow: International Relations.

12. Krapan, G. S. (2009). Constitutional and legal basis of protection of citizens rights to land. PhD thesis presented at the Russian Academy of Public Administration under the President of the Russian Federation, Moscow.

13. Kurochkin, S. A. (2007). Arbitration trial of civil cases in the Russian Federation: Theory and practice. Moscow: Wolters Kluwer.

14. Lebedev, S. N. (1999). International commercial arbitration and interim measures. Moscow journal of international law, 1, 62-63.

15. Melnikov, R. O. (2017). International experience of judicial protection of land rights and resolution of land disputes: Experience and prospects of development in Russia. Agrarian and land law, 6: 84-88.

16. Perozhok, E. A. (2017, March 23-24)). The settlement of land disputes in the arbitral tribunals. In Actual problems of modern forms of protection of the rights and freedoms of man and citizen. Collection of scientific articles and abstracts on the materials of the International scientific-practical conference. Veliky Novgorod, Novgorod State University.

17. Petrenko, O. V. (2016). Recognition of ownership of real estate in arbitral tribunals. Property relations in the Russian Federation, 1, 86-87.

18. Rosenberg M. G. (2004). Practice of the International Commercial Arbitration Court at the Chamber of Commerce and Industry of the Russian Federation for year 2003. Moscow: Statut.

19. Sevastyanov, G. V. (2013). The legal nature of arbitration and the competence of the arbitral tribunal in the sphere of real estate. $\mathrm{PhD}$ thesis presented at the Institute of State and Law of the Russian Academy of Sciences. 
20. Shekunova, Y. N. (2018). Arbitral tribunals and real estate rights. In S. I. Suslov (Ed.), Modern problems of law-making and law enforcement. Materials of the all-Russian scientific-practical conference, March 23, 2018, Irkutsk, Irkutsk Institute (branch) of the Russian State University of Justice.

21. Skvortsov 0. Y. (2010). Arbitration in the Russian Federation. Moscow: Wolters Kluwer.

22. Tarasov, V. N. (2002). Arbitration process. Saint-Petersburg: SPPDTS.

23. Vladimirova, S. A. (2007). Legal nature and significance of the arbitration agreement. $\mathrm{PhD}$ thesis presented at the Moscow University of the Ministry of Internal Affairs of Russia.

24. Zaitsev A. I. (2017, March 23-24). The Efficiency of dispute resolution in the arbitral tribunal - wishful thinking and normative validity. In Actual problems of modern forms of protection of the rights and freedoms of man and citizen. Collection of scientific articles and abstracts on the materials of the International scientific-practical conference. Veliky Novgorod: Novgorod state University. 